2013

\title{
Tolkien's Japonisme: Prints, Dragons, and a Great Wave
}

\author{
Michael Organ \\ University of Wollongong, morgan@uow.edu.au
}

\section{Publication Details}

Organ, M. 2013, 'Tolkien’s Japonisme: Prints, Dragons, and a Great Wave', Tolkein Studies, vol. 10, pp. 105-122.

Research Online is the open access institutional repository for the University of Wollongong. For further information contact the UOW Library: research-pubs@uow.edu.au 


\title{
Tolkien’s Japonisme: Prints, Dragons, and a Great Wave
}

\begin{abstract}
The original September 1937 George Allen \& Unwin edition of The Hobbit features artwork by J.R.R. Tolkien along with an accompanying dust jacket. This latter work is a modern, stylized graphic design composed of a not entirely symmetrical view of a Middle-earth landscape (night to the left, day to the right), with the Lonely Mountain rising in the distant center, flanked by steeply sloped, snow-covered Misty Mountains and in the foreground Mirkwood's dense, impenetrable forests. Additional features include a crescent moon, the sun, a dragon, eagles, a lake village, and a rapier-like path — a straight road — heading toward a darkened, megalithic trapezoidal door at the base of the mountain.1 The runes which form the border read: "The Hobbit or There and Back Again, being the record of a year's journey made by Bilbo Baggins; compiled from his memoirs by J.R.R. Tolkien and published by George Allen \& Unwin."
\end{abstract}

\section{Keywords}

japonisme, prints, dragons, tolkien, great, wave

\section{Disciplines}

Arts and Humanities | Social and Behavioral Sciences

\section{Publication Details}

Organ, M. 2013, 'Tolkien’s Japonisme: Prints, Dragons, and a Great Wave', Tolkein Studies, vol. 10, pp. 105-122. 


\title{
Tolkien's Japonisme : Prints, Dragons and a Great Wave
}

\author{
Michael Organ
}

The original September 1937 George Allen \& Unwin edition of The Hobbit features artwork by J.R.R. Tolkien along with an accompanying dust jacket $(H)$. This latter work is a modern, stylised graphic design composed of a not entirely symmetrical view of a Middle-earth landscape (night to the left, day to the right), with the Lonely Mountain rising in the distant centre, flanked by steeply sloped, snow covered Misty Mountains and in the foreground Mirkwood's dense, impenetrable forests. Additional features include a crescent moon, the sun, a dragon, eagles, a lake village and rapier-like path - a straight road - heading towards a darkened, megalithic trapezoidal door at the base of the mountain. [Note 1: In Tolkien's Middle-earth mythology, the "straight road" leaves the curvature of the earth and moves through the sky and space to the Undying Lands or Aman, a continent to the west of Middleearth which at the end of the Second Age was removed from the surface of the earth. Immortals reside there, though ring-bearers Bilbo and Frodo Baggins were taken on Elven ships over an ethereal sea to Valinor, in the middle of Aman ( $S 338)]$. The runes which form the border read: "The Hobbit or There and Back Again, being the record of a year's journey made by Bilbo Baggins; compiled from his memoirs by J.R.R. Tolkien and published by George Allen \& Unwin."

The dust jacket is considered a classic of modern graphic design, notable for its layout, harmonious balance of colour and symbolic richness. It remains in print with both hard and soft cover editions of The Hobbit published by HarperCollins, successors to George Allen \& Unwin (Collier). Such is the status of this artwork, Tolkien's final draft - part of the Tolkien Collection 
at the University of Oxford's Bodleian Library (MS. Tolkien drawings 32) - featured in the Treasures of the World's Great Libraries exhibition mounted in 2002 by the National Library of Australia (Treasures). Whilst an intimate study of the dust jacket reveals the process of creation - an early draft survives - in the case of Tolkien we need to look beyond traditional biographical and literary studies to artistic influences. For example, the flat perspective, simple design and blocks of colour utilized by Tolkien - blue, green and black - are suggestive of Japanese ukiyo-e woodblock prints from the Utagawa period, as best seen in the work of Katsushika Hokusai (1760-1849) and Utagawa Hiroshige (1797-1858). Was Tolkien aware of such prints and Japanese arts, crafts and mythology? Did he, like many turn of the century artists, exhibit his own form of Japonisme as a manifestation - knowing or unknowing - of such influences? [Note 2: Japonisme is a French term for a specific art style exhibited during the latter part of the nineteenth century and refers to those artists whose work reflected Japanese influence. It is now more broadly applied and extended into the early years of the twentieth century (Wichmann 8-14).]

Tolkien is not usually considered a Japanophile, with only a single reference to that country amongst his voluminous published correspondence - a letter written during the last months of World War Two commenting on Japan's imminent surrender following the dropping of the atomic bombs at Hiroshima and Nagasaki (Letters 116). Indirectly there is another, for as early as 1914, whilst an undergraduate at Oxford University, Tolkien purchased Japanese woodblock prints for his rooms at Exeter College (Carpenter 69). The paucity of first-hand accounts and direct mention of Japan by Tolkien may imply a lack of knowledge or interest. In contrast, elements of his art suggest otherwise, with The Hobbit dust jacket a case in point. 


\section{Middle-earth and Mount Fuji}

During Japan's period of isolation from the outside world between 1641 and 1854 it developed a distinct art form based around the woodblock print. These small, fragile images on rice paper displayed vibrancy in colour, design and subject matter, whilst their production involved expert craftsmanship in both the cutting of blocks and laying of paint. Typically woodblock prints portrayed landscapes of picturesque localities throughout Japan, aspects of life in population centres such as Edo (Tokyo) and around the Yoshiwara pleasure precinct, portraits of famous kabuki actors, botanical and scientific studies, and mythological subjects such as ghosts, demons and, with the latter group reflecting the richness of Japanese folklore and story-telling (Hunter, Piggott). Tolkien's interest in the subject of dragons from earliest childhood would have attracted him to such works (Evans 22; Hargrove). The ukiyo-e print flourished through the years of isolation as artists, engravers and publishers combined to produce an ever changing array of prints and hangings to grace the walls of residences, public buildings and entertainment venues. Woodblock prints were also used in books ('manga') to illustrate text and as a precursor to the modern comic and graphic novel (Harris 10-51).

When copies of Japanese prints, hangings and elaborately designed textiles such as the kimono first reached Europe in large numbers during the 1870s they caused a sensation. The distinctive use of colour and design immediately attracted the attention of French Impressionists. Artists who openly championed Japanese art during this period included Manet, Degas, Toulouse-Lautrec, Van Gogh, Gauguin, Klimt and, much later, Picasso (Ives;

Serra 24-49). Stimulated by the 'new' Japanese style, Western artists produced numerous examples of graphic design, pottery, prints and gallery-quality paintings with direct reference to 
Japanese art in composition, colour and content (Wichmann 23-73). The term Japonisme entered the language in connection with commentary and criticism. Japanese art and craft, being ideally suited to book illustration, also saw acceptance in an area which, since the early part of the nineteenth century, had been dominated by the steel engraving. A good example is John Tenniel's illustrations for Lewis Carroll's Alice in Wonderland, first issued in 1865. Posters and prints requiring splashes of colour commonly utilized lithography, however by the end of the century full colour half-tone and photographic processes were being used more widely, especially in circumstances requiring large print runs. A fin-de-siècle explosion in the arts took place following on, and concurrent with, the discovery of Japan's rich artistic heritage and the appearance of movements such as Impressionism, Expressionism, Pre-Raphaelitism, Symbolism, Art Nouveau, Abstraction and the catch-all Modernism (Mortimer 114).

The first decades of the twentieth century provided a rich environment in which the young J.R.R. Tolkien - born in 1892 - could develop his interest in, and expertise around the basic rudiments of drawing in pen, ink and watercolour, both for his own enjoyment and as an adjunct to his writing. Though only having received informal training from his mother - who died when he was 12 - Tolkien reached a level of skill and competency as an artist which is reflected in the works he produced for The Hobbit. And whilst repeatedly downplaying any talent in this area, he nevertheless possessed the necessary expertise and drive to provide all the pictorial material for this, his first publication aimed at a general audience. He also published a work of fiction in 1942 - Leaf by Niggle - which featured an artist as the main character and is, in part, autobiographical (Leaf). 
In recent years Tolkien's achievements as an artist have been highlighted in a number of publications. These include reminiscences by his daughter Priscilla ("My Father the Artist"), a picture book, calendars, a detailed discussion of selected works, an illustrated volume specifically on the art of The Hobbit, and numerous articles and websites (Pictures; Artist \& Illustrator; Art of The Hobbit; Arwen-undomiel; Ellison; Paterson). Within these often discursive texts, direct influences on Tolkien's painting, drawing and design work have been identified or suggested, including artists operating in the folklore tradition such as the English Walter Crane, Arthur Rackham and Audrey Beardsley, and the Russian Ivan Bilibin (Anonymous (2); Garth; Jones; Maliszewski; McLeod \& Smol; Menofgondor). Apart from connections based on general comparisons in style, Tolkien is also known to have directly copied and/or adapted the work of Scandinavian Kay Nielsen, Archibald Thorburn and Jennie Harbour for specific illustrations in The Hobbit (Podles; H). Whilst much of his art comprises simple landscapes, designs and subjects specifically related to his writing, Tolkien was also open to experimentation and new trends in art. For example, between 1911 and the late 1920s he compiled a folio of works under the general heading The Book of Ishness, containing phantasmagoric, abstract and symbolic works, many of which are rendered in vibrant watercolour and lightly done (Reader's Guide 52-3; Unruh). Ishness appeared around the same time as Tolkien purchased Japanese woodblock prints and was, in turn, influenced by them.

The most comprehensive study of his art to date - Hammond \& Scull's J.R.R. Tolkien: Artist and Illustrator - is indispensible in gaining an appreciation of the variety and extent of his work, ranging from landscapes, figurative pieces and maps through to graphic designs including patterns and book covers. The authors' encyclopedic knowledge of Tolkien makes it a rich source of information on some 200 individual works out of the more than 800 known to 
exist. The book adopts a theme-based approach throughout, as opposed to the chronological method traditionally applied in surveys of individual artists. It is therefore somewhat limited in enabling assessment of the development of Tolkien's art over time, both in regards to technique and subject matter. No clear picture emerges. Scull and Hammond's inclusion within the Reader's Guide of a summary entry on 'Art' is welcome, as is the comprehensive list of works illustrated in a variety of publications (Reader's Guide 53-5; Chronology 828-840). Two posthumous exhibition catalogues featuring works from Oxford University's Bodleian Library are also enlightening (Drawings; Life and Legend). Siegfried Wichmann, in the introduction to his expansive work on Japonisme, considers the inherent difficulties in unraveling the many and varied influences on a individual artist. He concludes:

The most convincing method of presenting a case in the study of the fine arts is through a series of pictorial examples, constructed according to a genetic principle. Such a series can illustrate the way in which any number of variants can branch off from a basic primary type.... It is an adaptable system and can be used for comparing thematic as well as technical matters, such as colour, form, line, depth, light and shade. (Wichmann 6)

We do not have the luxury of letters and diary entries by Tolkien discussing individual works and the various elements brought to bear in their production. Neither is there contemporary exhibition catalogues which elicited comment or commentary. A closer study of Tolkien's art is called for, with an approximate chronology developed to reveal associations between the evolution of his art and specific events in his life, such as the purchase of Japanese woodblock prints in 1914, the birth of his children between 1917 and 1929, and introduction to literary 
works such as the Old English epic poem Beowulf and the northern Volsunga Saga. References to developments in Tolkien's art are nevertheless provided by Hammond and Scull arising out of their own viewing of his many works. For example, we are informed that:

“...suddenly, in 1927-8, [Tolkien] was extraordinarily productive... His skill was greatly increased. At times he still used bright colours, but now these were applied with a mastery and subtlety not seen in his art before. His style remained dynamic but became more painterly, with such drawn outlines as there were now almost invisible" (Artist \& Illustrator 50).

Such significant assessments of his progress as an artist are often buried amongst densely written discussions around the mythology of Middle-earth. The failure to date works illustrated throughout Artist \& Illustrator - both precisely and approximately - despite this information often appearing in the text, is problematic. Dramatic changes took place at various periods in Tolkien's life, and whilst it may be easy to connect these to literary influences and the development of an increasingly complex Middle-earth mythology, it is also likely that his knowledge of, and interaction with the fine arts had effect. Apart from works seen by Tolkien on the walls of art galleries, the fact of his being a widely read scholar and teacher suggests he would have encountered illustrated volumes of folklore and mythology from which to draw inspiration. These may have included Asian and Middle Eastern examples and reproductions of Japanese woodblock prints. Did such encounters influence Tolkien and his art, and if so, to what degree? In attempting to answer these questions we can start our investigations with mountains, a subject Tolkien made good use of in the development of a Middle-earth topography. 
The steep mountains which feature in Tolkien's dust jacket for The Hobbit are based in part on what he encountered during a walking tour of the Swiss Alps in 1911 (Atherton 131-8). Drawings from that time feature the mountains and their distinctive, rugged snow-capped peaks. They appear in many of his subsequent writings with, for example, the Silberhorn transformed into Middle-earth's Silvertine and Celebdil (Forster 552; Letters 391-3). Some of Tolkien's images of mountains from the 1920s onwards are suggestive of Japan's sacred Mount Fuji, the focus of numerous works by Japanese ukiyo-e artists (Forrier). Mount Fuji's almost perfect triangular form differs in silhouette from the more ragged and uplifted European peaks in the matter of its majestic symmetry and smooth slopes when viewed from a distance. The isolation and domination of a surrounding largely flat landscape also enhances its iconic status. Tolkien's fondness for isolated mountain peaks in the Mount Fuji style - usually an extinct or erupting volcano - is seen in The Sillmarillion (the White Mountain or Taniquetil), The Hobbit (the Lonely Mountain) and The Lord of the Rings (Mount Doom). Beyond mountains, landscape and environment in general are important elements of Tolkien's storytelling and often imbued with character. For example, in The Hobbit the Arkenstone is "the heart of the mountain" and within The Lord of the Rings Ents are a living embodiment of the forest (Atherton 73-5).

The presence of mountains as a design element in The Hobbit dust jacket is foreshadowed in a number of Tolkien's Christmas letters to his children (Letters from Father Christmas). Compiled between 1920 and 1943, they comprise letters and envelopes featuring illuminated handwriting by Tolkien alongside paneled illustrations and 'official' North Pole stamps on the covers. For example, the illustration North Polar Bear Karhu 1931-32 is a simple two colour drawing in dark green and red ink featuring two symmetrical mountains around a 
central rising sun (Artist \& Illustrator 72; Letters from Father Christmas 73). The spike North Pole which features in many of these Christmas illustrations is obviously a precursor to the two towers featured in The Lord of the Rings - Saruman's Orthanc at Isengard and Sauron's Barad-dur or Dark Tower. Most intriguing and of relevance to the present discussion, however, is Tolkien's drawing of a stamp for the 1925 Christmas envelope, bearing a striking similarity to The Hobbit dust jacket (Letters from Father Christmas 19). Using a different 3-colour palette of red, black and purple, elements of the work include symmetrically placed conical peaks, a central North Pole feature instead of the later Lonely Mountain, and a darkened sky highlighted by a crescent moon and opposing sun. The same basic design was utilised just over a decade later for The Hobbit dust jacket. A comparison of Tolkien's series of Father Christmas letters with works reproduced in Artist and Illustrator reveals subtle changes occurred in his depiction of mountains over the years between the Swiss Alps excursion and publication of The Hobbit, reflecting Japanese influences.

Tolkien's purchase of Japanese prints in 1914 formed part of a growing collection, though we have no detail as to the extent or precise content. According to Carpenter - who had access to unpublished manuscripts and interviews with immediate family members - Tolkien's art was "suggestive of his affection for Japanese prints" (Carpenter 163; Willett 62). Hammond and Scull in Artist and Illustrator play down the influence of Japanese prints, suggesting:

Such prints were popular at the time, and do not seem to have had much influence on his own art except perhaps to suggest to him, for works such as the watercolour Glorund Sets Forth to Seek Turin, a simplification of natural forms 
and the use of flat colour for pattern effect rather than for modeling" (Artist \& Illustrator 9).

It could be argued that these very points support the view that Japanese woodblock prints were a decided influence on Tolkien and help explain why Carpenter made the connection he did. We can see this influence in drawings, watercolours and designs from the 1910 s through to the 1930s. Tolkien was not alone in being so affected, for Japonisme is evident in the work of many British artists from this period. A good example is the late Pre-Raphaelite Edward Burne-Jones and his engravings for the Kelmscott Chaucer, a book Tolkien would undoubtedly have been aware of (Chaucer; McCann; Ogawa). English artist Walter Crane - identified by Hammond \& Scull as an influence on Tolkien - was a leading student of Japanese art and devotee of the Middle Ages. Crane's work highlighted the connection between the art and craft of Japanese woodblocks - which he called "a living art, an art of the people, in which traditions and craftsmanship were unbroken and the results full of attractive variety, quickness and naturalistic force" (Wichmann 8) - and the work of the English Pre-Raphaelite artists such as Dante Gabriel Rossetti and the writer, poet and publisher of the Kelmscott Press, William Morris. The Pre-Raphaelites looked to medieval arts and crafts for inspiration, producing brightly coloured works in defiance of the somber tones preferred by the Royal Academy. Morris was an especially significant influence on the young Tolkien. With Japanese arts, designs and crafts entering Britain during the first decades of the twentieth century, and the work of local artists reflecting the impact of such influences, it is not surprising that Tolkien took elements on board and re-used or adapted them within his art and writing. 
Mark Atherton's recent book on the origins of The Hobbit draws a comparison between the mountains in Tolkien's watercolour of the dragon Glorund emerging from the entrance to Nargothrond and those commonly seen in Japanese prints (Atherton 42-3). The large mountain in the distance is reminiscent of Mount Fuji, whilst the depiction of the dragon is influenced by Tolkien's reading of Beowulf. The Glorund watercolour dates from September 1927 and is a significant work in the artist's oeuvre. It is also somewhat similar in layout to The Hobbit dust jacket, with the central mountain flanked by conical forms, though to a lesser degree and not as symmetrical. The dragon is horned, unlike The Hobbit's Smaug, and more lizard-like. It has been noted that the style is similar to Lancelot Speed's illustration in Andrew Lang's The Red Fairy Book of 1895, from which Tolkien first encountered the dragon Fafnier and the Nibelungen saga (Atherton 42-3; Hart 10).

Tolkien's depiction of dragons evolved over time, and most especially in the decade between drawing Glorund and Smaug (Reader's Guide 215-22). Whilst Glorund was in part a traditional, flightless European dragon, latter depictions are mostly variants of the Japanese / Chinese dragons of mythology - serpentine, scaled, with 3 or 4 toed claws, long spiraling tail, wings and a face displaying almost human-like character (Giovannitti and Sanders ; Shuker). The Chinese dragon has horns; the Japanese does not, and neither does Tolkien's Smaug, though Glorund is horned. Examples of the Japanese dragon can be seen in modern Studio Ghibli anime features Spirited Away and Howl's Moving Castle, wherein humans transform into flying dragons at will. And whilst Smaug was not a shape shifter, he was given human character and failings by Tolkien. The dragon in his watercolour Conversation with Smaug from The Hobbit series is almost identical to the beast depicted by Katsushika Hokusai in a number of woodblock and screen prints from the nineteenth century, which in turn can be 
traced back to the $13^{\text {th }}$ century Chinese works such as Ch-en Yung's Dragons among waves (Frunzetti and Stanculescu 43). Hokusai's famous print from his multi-volume Manga of the Dragon Fudou eating the devil-subduing sword Kurikara brings to mind not only Tolkien's depiction of Smaug but the three swords which feature in The Hobbit - Sting, Orcrist and Glamdring. Hokusai's other famous dragon works include flights about Mount Fuji, reminding us of those variant drawings by Tolkien depicting the White Dragon pursuing Roverandom and the Moondog, and Smaug circling the Lonely Mountain (Forrier; Artist \& Illustrator 81, 142-3; Art of The Hobbit). It is possible that Tolkien was drawing on Japanese art and mythology in developing this aspect of The Hobbit narrative.

A further manifestation of Tolkien's art is his use of calligraphy, which features in both published and unpublished works. A connection has been suggested between the distinctive monogram he developed in that hand and which now appears as a trademarked logo on all his official publications, and the Japanese calligraphy for the word soku (Kane, 2009). Tolkien would have encountered Japanese characters in his collection of woodblock prints, the majority of which bear calligraphic inscriptions describing the subject of the work and the artist responsible. Tolkien's monogram was commonly applied in his art, and can be seen on the lower right corner of The Hobbit dust jacket. Early examples were of the traditional, nonsymmetrical form utilizing the letters JRRT. However one of his drawings dated 31 August 1912 shows the symmetrical monogram in the Japanese style, suggesting an awareness of Japanese calligraphy from at least that point (Artist \& Illustrator 18). The final version of the monogram maintains this connection, though with additional refinements. 
In seeking additional evidence and examples of Japanese influences on Tolkien's art, recent internet postings provide a rich resource. Roh_wyn, a correspondent on the Menofgondor internet forum, noted a similarity between Tolkien's watercolour of Taniquetil the White Mountain or Holy Mountain of Arda (Artist \& Illustrator 56) - and Japanese woodblock prints such as Hiroshige's Mount Fuji seen across a plain c.1850 (Forrier; Menofgondor). Both works feature a solitary, snow-covered conical peak dominating the surrounding landscape and similar use of colour, composition and application. The Russian blog 'Wave propagation' points out a connection between Hokusai's woodblock print The Great Wave off Kanagawa and Ivan Bilibin's illustration of a barrel being hit by a wave, as published in The Tale of Tsar Saltane (Pushkin) [Note 3: The original Hokusai print was published sometime during 1830-1 as part of a series entitled (in English) Thirty six Views of Mount Fuji. Originally labeled 'Kanagawa oki name ura' - which translates as 'In the hollow of a Wave off the Coast at Kanagawa', in Tokyo Bay - the print is now more commonly known as 'The Great Wave off Kanagawa.]. Bilibin's wave is very much in the distinct animated fractal style of Hokusai's. In turn, The stone of the hapless blog connects the Bilibin work with Tolkien's watercolour Bilbo comes to the Huts of the Raft-elves, as published in The Hobbit. The comparison is based primarily on subject matter and, to a lesser degree, the colour palette and rune-like borders. There the direct similarity ends, apart from the fact that both the Bilibin and Tolkien works are illustrations for books of the mythology genre. Such convolutions of connectivity reflect the difficulties in isolating artistic influences, especially for an artist such as Tolkien who rarely discussed his art in detail, preferring instead to reflect upon literary achievements. 
Tolkien, in his famous 1939 Lecture on Fairy-stories, commented briefly on the role of art as a supplement to text, though it was very much a negative view presented. He held that: "However good in themselves, illustrations do little good to fairy-stories" (OFS 81-2; (Artist \& Illustrator 187). He also made isolated remarks about the morbidity of Surrealist works in a footnote to the lecture notes. Such comments perhaps grew from Tolkien's frustration in not being able to portray through his painting and drawing the complexity and depth of stories which grew from his fertile imagination, especially in regards to figures. This is understandable, however such a view is not one that generally applies. We can see, for example, with Hokusai's The Great Wave off Kanagawa that a work of art can succeed beyond measure in capturing a moment in time and portraying what mere words cannot, in this instance the awesome power of nature. Hokusai, as one of the greatest exponents of Japanese woodblock art, was prolific, popular and extremely influential in the wake of Japonisme. His print The Great Wave off Kanagawa is the most famous of all ukiyo-e works and has been copied and adapted on numerous occasions since first 'discovered' and analyzed by French artists such as Manet in the 1870s (Clark). A link may exist between Tolkien's dust jacket design for The Hobbit and The Great Wave off Kanagawa. Both works are dominated by triangular forms - in the former the Lonely Mountain and Misty Mountains, in the latter the unbroken and breaking waves, with Mount Fuji in the distant background. Both prints display the aforementioned flatness of a nevertheless powerful landscape, and a limited colour palette dominated by Prussian Blue. Tolkien's work has a lightness of tone and application of line in keeping with the ukiyo-e style, though the Art Nouveau curved sections which feature along the lower section of the work reminds us this is a work from the 1930s and not a hundred years previous. In the dust jacket the Misty Mountains are hills like waves and, in converse, Tolkien's waves as 
featured in his writings are "like mountains moving" or "hills rolling" (Sauron 251, 290). Hokusai's waves are in turn like mountainous hills in motion. In Smith of Wootton Major from 1967 Tolkien makes a rather prosaic reference to water, waves and mountains in relation to the experiences of the main character of that work:

When he first began to walk far without a guide he thought he would discover the further bounds of the land; but great mountains rose before him, and going by long ways round about them he came at last to a desolate shore. He stood beside the Sea of Wilderness Storm where the blue waves like snow-clad hills roll silently out of Unlight to the long strand, bearing the white ships that return from battles on the Dark Marches of which men know nothing. He saw great ships cast high upon the land, and the waters fell back in foam without a sound (Quoted in Birzer).

Hokusai's dramatic representation of a breaking wave about to overwhelm boats full of men would have resonated with the author of The Hobbit, for reasons little known to the public at the time of the book's initial publication, though relating to a significant area of Tolkien's personal experiences whereby writing and art come together.

The Great Wave

Throughout his life J.R.R. Tolkien was haunted by the nightmarish dream of a great wave bearing down upon the countryside or ocean before him and sweeping him away. Tolkien would wake from sleep with a start, gasping for breath as if drowning and questioning the origin and meaning of this traumatic experience. The dream tormented him from earliest memory, though abated somewhat after elements of it were put down on paper in the form of 
the tale of the destruction of Númenor, an ancient land to the west of Middle-earth. This retelling of the Atlantis myth began in the mid thirties, just prior to publication of The Hobbit. It subsequently took numerous forms - as The Last Tale: The Fall of Númenor, chapters within The Lost Road; and as the tale of Akallabeth within The Sillmarillion (Chronology 180; Moss, 2011, 2012; Finduilas; Mitchell). Within the abandoned novel "The Notion Club Papers", written around 1945, Tolkien made further references to a great wave, in the context of a meandering discussion between the Club's members on the topic of dreams. One of the characters, Michael George Ramer, recounts that within one of his many dreams:

There is a Green Wave, whitecrested, fluted and scallop-shaped but vast, towering above green fields, often with a wood of trees, too; that has constantly appeared. (Sauron 194)

During writing of The Lord of the Rings Tolkien gave the experience to one of the characters, wherein towards the end of The Return of the King Faramir says to Eowyn, whilst standing on the walls of Minas Tirith as the Ring is being destroyed, that he is reminded of an ominous "great and dark wave climbing over the green lands and above the hills, and coming on, darkness unescapable. I often dream of it" (LOTR 941). In a later letter to fellow author W.H. Auden, dated 7 June 1955, Tolkien publically noted the intensity and impact of this dream:

I say this about the 'heart', for I have what some might call an Atlantis complex. Possibly inherited, though my parents died too young for me to know such things about them, and too young to transfer such things by words. Inherited from me (I suppose) by one only of my children, [note: Tolkien's second son Michael.] though I did not know that about my son until recently, and he did not know it about me. I 
mean the terrible recurrent dream (beginning with memory) of the Great Wave, towering up, and coming in ineluctably (5) over the trees and green fields. (I bequeathed it to Faramir.) I don't think I have had it since I wrote the 'Downfall of Númenor' as the last of the legends of the First and Second Age. (Letters 213)

Tolkien went on to repeat reference to the dream and its significance in a number of letters, including the following draft to an American correspondent 'Mr Thomson', dated 14 January 1956:

Out of that came the 'missing link': the 'Downfall of Númenor', releasing some hidden 'complex'. For when Faramir speaks of his private vision of the Great Wave, he speaks for me. That vision and dream has been ever with me - and has been inherited (as I only discovered recently) by one of my children [Michael]. (Letters 232)

In a later letter to Christopher Bretherton, dated 16 July 1964, Tolkien states in relation to development of The Lord of the Rings:

Another ingredient, not before mentioned, also came into operation in my need to provide a great function for Strider-Aragorn. What I might call my Atlantis-haunting. This legend or myth or dim memory of some ancient history has always troubled me. In sleep I had the dreadful dream of the ineluctable Wave, either coming out of the quiet sea, or coming in towering over the green inlands. [Note 4: Ineluctable : unable to be avoided; inescapable; inevitable (c.f. Nenyia).] It still occurs occasionally, though now exorcized by writing about it. It always ends by 
surrender, and I awake gasping out of deep water. I used to draw it or write bad poems about it. When CS. Lewis and I tossed up, and he was to write on spacetravel and I on time-travel, I began an abortive book of time-travel of which the end was to be the presence of my hero in the drowning of Atlantis. This was to be called Númenor, the Land in the West. (Letters 347)

And in a letter to Dick Plotz of the Tolkien Society of America, dated 12 September 1965, Tolkien records:

Of all the mythical or 'archetypal' images this [the Atlantis myth] is the one most deeply seated in my imagination, and for many years I had a recurrent Atlantis dream : the stupendous and ineluctable wave advancing from the Sea or over the land, sometimes dark, sometimes green and sunlit. (Letters 361)

Within "The Notion Club Papers" Tolkien discusses at length on the origin, meaning and variety of dreams, many of which are likely a reflection of his own experiences. In seeking an explanation he raises the subject of previous lives as an inexplicable source for dreams and thoughts of imagination. Of the great wave dream and art, it is interesting to note Tolkien's comment in the letter to Christopher Bretherton that he "used to draw it or write bad poems about it." Scull and Hammond refer to a 15 March 1914 production of a watercolour of the sea "or possibly of the Great Wave which sometimes haunts his dreams" and identify possible extant artworks and prose such as "The Horns of Ylmir" pertaining to this comment (Chronology 51; Reader's Guide 69). That this should occur around the time Tolkien was known to have purchased Japanese woodblock prints and also commenced compilation of his sketchbook The Book of Ishness is perhaps coincidental (Chronology 49). It may reflect his 
awareness of Japanese art and works such as Hokusai's Great Wave off Kanagawa, or a transformation from the dreamscape into an evolving Middle-earth context. As Olag-Hai points out, the tsunami-like references in the tale of the destruction of Númenor and Faramir's reminiscences are, uncharacteristically for Tolkien, "born out of images rather than languages" (Olag-Hai). Whilst Tolkien was keen to promote the fact that in his writing it was often the word that came first, followed by development of the tale (viz. 'Hobbit'), there is no doubt that in evolving his immensely complex Middle-earth mythology personal experiences, readings and encounters with art and imagery played an important and ongoing role. The connection is frequently drawn, for example, between his experiences at the Battle of the Somme in World War One and subsequent accounts of war in The Lord of the Rings. The recurring dream of a great wave was utilized in a similar manner, as both an intellectual and emotional source for storytelling. Works such as Hokusai's Great Wave off Kanagawa and Walter Crane's Symbolist masterwork Neptune's Horses of 1892 bring to mind the wave which swept away the Nazgûl at the Ford of Bruinen within Tolkien's The Lord of the Rings, and lines from "The Horns of Ylmir":

.... The torrents gathered and the leaping billows ran,

Till the foam-haired water-horses in green rolling volumes came -

A mad tide trampling landward.... (The Shaping of Middle Earth 216)

Definitive connections between Tolkien, his art and Japanese woodblock prints remain elusive. The use of Japanese technique and imagery was, from around 1912, an element of the Modernist approach he brought to his art, in seeking to reinvent what is and utilizing what was, just as works such as The Lord of the Rings and the evolving Middle-earth legendarium were a literary expression of this desire to invent and reinvent (Mortimer 116). Tolkien's 
knowledge of, and appreciation for Japanese art can also be inferred from somewhat cryptic, though positive comments he made late in life after viewing the 1965 Japanese edition of The Hobbit, featuring illustrations by Ryuichi Terashima. In a letter to Rayner Unwin dated 15 December of that year, Tolkien commented: "Much could be said about the pictures: in many ways astonishing" (Reader's Guide 421). There is the suggestion within this that Tolkien not only well informed regarding Japanese art but was also very impressed with the manner in which Terashima interpreted his work. And in a meeting the following year Clyde S. Kirby noted: "[Tolkien] showed me with particular pleasure the frontispiece which portrayed Smaug falling convulsively over dale" (Kirby 23). Future studies of the more than 800 works of art by Tolkien may reveal definitive connections and influences. Until then, we are left with a few fragments of evidence and mere opinion gained from viewing individual artwork.

It remains a fact that one of the greatest writers of the twentieth century is responsible for an iconic work of art in The Hobbit dust jacket that was produced not by mere chance but as a result of perseverance, skill and artistic expertise. The influence of Japanese woodblock prints in its creation is strongly suggested, though not proven. Perhaps the final comment on this subject can be left to British fantasy author Terry Pratchett who, in 2001, noted in regards to our subject's place in the history of fantasy fiction writing:

Tolkien appears in the fantasy universe in the same way that Mount Fuji appeared in old Japanese prints. Sometimes small, in the distance, and sometimes big and close-to, and sometimes not there at all, and that's because the artist is standing on Mount Fuji. (Pratchett). 


\section{Works Cited}

Anonymous. "The Great Wave (Faramir's dream)." [Blog] 2005. Available URL:

http://users.abo.fi/jolin/tolkien/inspirations/great wave the faramirs dream.htm

----. "Wave propagation." [Blog] 2010. Available URL:

http://riowang.blogspot.com/2010/05/wave-propagation.html.

Arwen-undomiel. J.R.R. Tolkien Gallery. [Website] 2012. Available URL: http://www.arwenundomiel.com/tolkien.html.

Atherton, Mark. There and Back Again: J.R.R. Tolkien and the Origins of the Hobbit. London: I.B. Tauris, 2012.

Birzer, Bradley J. J.R.R. Tolkien On Entering Faerie. [Blog] 8 May 2012. Available URL: http//payingattentiontothesky.com/2012/05/08/j-j-r-tolkien-on-entering-faerie.

Carpenter, Humphrey. J.R.R. Tolkien: A Biography. London: George Allen \& Unwin, 1977.

Chaucer, Geoffrey. The Works of Geoffrey Chaucer. Hammersmith: Kelmscott Press, 1896.

Clark, Timothy. Hokusai's Great Wave. London: British Museum Press, 2011.

Collier, Pieter. "Books by J.R.R. Tolkien - The Hobbit - Editions." Tolkien Library. [Website] 2012. Available URL: http://www.tolkienlibrary.com/booksbytolkien/hobbit/editions.htm.

Drawings by Tolkien [Exhibition catalogue] (December 1976 - February 1977), Oxford: Ashmolean Museum and The National Book League, 1977. 
Ellison, John. "Tolkien's Art." Mallorn 30 (1993): 21-28.

Evans, Jonathan. "The Dragon-lore of Middle-earth: Tolkien and Old English and Old Norse Tradition." In George Clarke and Daniel Timmons (editors) J.R.R. Tolkien and His Literary Resonances. Westport: Greenwood Press, 2000, 21-38.

Finduilas. "Númenor Essay." Finduilas's J.R.R. Tolkien Page. [Website] 2012. Available URL: http://fin.yserve.net/html/numenor.htm.

Forrier, Matthi. Hiroshige: Prints and Drawings. Munich: Prestel, 2011.

----, Hokusai: Prints and Drawings. Munich: Prestel, 2010.

Foster, Robert. Tolkien's World from A to Z: The Complete Guide to Middle-earth. New York: Del Ray, 2001.

Frunzetti, Ion and Stanculescu, Nina. Classical Chinese Painting. London: Abbey Library, 1979.

Garth, John. "Artists and Illustrators' Influence on Tolkien." J.R.R. Tolkien Encyclopedia: Scholarship and Critical Assessment. Ed. Michael D.C. Drout. New York: Routledge, 2007.

Giovannitti, Alayna and Sanders, Arnie. "The 1938 Hobbit: An exhibit and public reading sponsored by the Brooke and Carol Peirce Center for Undergraduate Research in Special Collections and Archives." [Webpage] 26 September 2009. Available URL: http://faculty.goucher.edu/eng330/hobbit_project.htm. 
Hammond, Wayne G. and Scull, Christina. J.R.R. Tolkien: Artist \& Illustrator. London: HarperCollins, 1995.

-----, The Art of The Hobbit by J.R.R. Tolkien. London: HarperCollins, 2011.

Hargrove, Eugene C. "Dragons in the Writings of J.R.R. Tolkien." [Webpage] 31 December 2007. Available URL: http://www.cep.unt.edu/ hagrove.dragons.html.

Harris, Frederick. Ukiyo-e : The Art of the Japanese Print. Tokyo: Tuttle Publishing, 2010.

Hart, Rachel. "Tolkien, St. Andrews, and Dragons." In Trevor Hart and Ivan Khovacs (eds.) Tree of Tales: Tolkien, Literature, and Theology. Texas: Waco, 2007.

Hunter, Jack. Dream Spectres: Extreme Ukiyo-e - Sex, Blood and the Supernatural. Tokyo: Shinbaku Books, 2010

Ives, Colta F. The Great Wave: The Influence of Japanese Woodcuts on French Prints. New York: The Metropolitan Museum of Art, 1974.

Jones, Jonathan. "Why Tolkien was a fine modern artist." Jonathanjonesonart blog [Blog], The Guardian, 29 November 2012. Available URL: http://www.guardian.co.uk/artanddesign/jonathanjonesblog.

Kane, Doug. "Tolkien and Oriental Calligraphy." Mythsoc Forum. [Website] 6 January 2009, available URL: http://groups.yahoo.com/group/mythsoc/message/20282.

Kirby, Clyde S. Tolkien and "The Silmarillion."Wheaton: Harold Shaw Publishers, 1976. 
Macleod, Jeffrey J., and Smol, Anna. "Single Leaf: Tolkien's Visual Art and Fantasy." Mythlore 27 (2008): 105-126.

Maliszewski, James. "Tolkien's Influence in Pictures." Grognardia - Musings and Memories from a Lifetime of Roleplaying. [Blog] 3 January 2011. Available URL: http://grognardia.blogspot.com.au/2011/01/tolkiens-influence-in-pictures.html.

McCann, Paul. “Japonisme in Britain: Burne-Jones, Beardsley, Sime.” The Victorian Web [Website]. 2008. Available URL:

http://www.victorianweb.org/art/illustration/sime/polm1.html.

Menofgondor. "Tolkien as an artist." Menofgondor Blog - forum. 2012. Available URL: http://www.menofgondor.com/forum/.

Mitchell, P.I. "Tolkien and the Atlantis Myth." [Website] 2012. Available URL: http://www3.dbu.edu/mitchell/numenoratlantis.htm.

Mortimer, Patchen. “Tolkien and Modernism.” Tolkien Studies 2 (2005): 113-129.

Moss, Robert. "Atlantis-haunted: Tolkien and the Bent World." The Robert Moss Blog 7 January 2011. Available URL: http://mossdreams.blogspot.com.

----, "Dream symbols - Tsunamis and Monster Waves." [Blog] 2012. Available URL: http://blog.beliefnet.com.

National Library of Australia. Treasures from the World's Great Libraries. "The Hobbit c.1936." [Exhibition] Canberra: National Library of Australia. 2002. Available URL: 
http://pandora.nla.gov.au/pan/37311/20030822-

0000/www.nla.gov.au/worldtreasures/html/theme-literature-1-hobbit.html.

Nenyia. "The Ineluctable Wave - a classical comparison of Númenor and Atlantis." The Council of Elrond. [Website] 2012. Available URL:

http://www.councilofelrond.com/litarticle/the-ineluctable-wave-a-classical-comparison-ofnumenor-and-atlantis/.

Olag-Hai. "The Science of Middle-earth: The Great Wave." Green Books- Exploring the Words and Worlds of J.R.R. Tolkien. [Blog] 2012. Available URL: http://greenbooks.theonering.net.

Ogawa, Ayako. Japonisme in Britain: Whistler, Menpes, Henry, Hornel and nineteenth-century Japan. London: Routledge, 2003.

Patterson, Nancy-Lou. "Tree and Leaf:. J.R.R. Tolkien and the Visual Image." English Quarterly 71 (1974): 11-26.

Piggott, Juliet. Japanese Mythology. London: Paul Hamlyn, 1969.

Podles, Mary. "Tolkien and the New Art." Touchstone (2002). Available URL: http:// http://www.touchstonemag.com/archives.

Pratchett, Terry. Interview with Therese Littleton. [Webpage] 2001. Available URL: http://www.au.Ispace.org/about-terry/interviews/amazon3.html.

Priestman, Judith. Tolkien: Life and Legend. [Exhibition Catalogue]. Oxford: Bodleian Library, 1992. 
Pushkin, Alexsandr. Skazka o Tsare Saltane [The Tale of Tsar Saltan]. St. Petersburg: Expeditsii Zagotovlenya Gosudarstvennykh Bumag. 1905.

Scull, Christina and Wayne G. Hammond. The J.R.R. Tolkien Companion and Guide: Chronology. Boston: Houghton Mifflin, 2006.

-----. The J.R.R. Tolkien Companion and Guide: Reader's Guide. Boston: Houghton Mifflin, 2006.

Serra, Pepe. Secret Images: Picasso and the Japanese Erotic Print. London: Thames \& Hudson, 2010.

Shuker, Karl. Dragons: A Natural History. London: New Burlington Books, 2004.

Tolkien, J.R.R. The Hobbit. London: George Allen \& Unwin, 1937.

-----. "Leaf by Niggle." Dublin Review 216 (January 1945): 46-61.

-----. The Lord of the Rings. London: George Allen \& Unwin, 3 volumes, 1954-5.

-----. The Hobbit. London: George Allen \& Unwin, 1975.

-----. The Silmarillion. Ed. Christopher Tolkien. London: George Allen \& Unwin, 1977.

-----. Pictures by J.R.R. Tolkien. London: George Allen \& Unwin, 1979.

-----, The History of Middle-earth: Volume IV: The Shaping of Middle-earth. Ed. Christopher Tolkien. London: HarperCollins, 1986. 
------, The History of Middle-earth: Volume IX: Sauron Defeated. Ed. Christopher Tolkien. London: HarperCollins, 1992.

-----. The Letters of J.R.R. Tolkien. Eds. Humphrey Carpenter with Christopher Tolkien. London: HarperCollins, 1995.

-----, Letters from Father Christmas. London: HarperCollins, 2004.

-----. "On Fairy-Stories." Tolkien On Fairy-Stories. Ed. Verlyn Flieger and Douglas A. Anderson. London: HarperCollins, 2008.

----- and Anderson, Douglas A. The Annotated Hobbit. New York: Houghton Mifflin, 2002.

Tolkien, Priscilla. "My Father the Artist." Amon Hen: Bulletin of the Tolkien Society. 23 (December 1976): 6-7.

Unruh, Wes. "Review of Wayne G. Hammond \& Christina Scull, J.R.R. Tolkien: Artist \& Illustrator (Houghton Mifflin Company 1995, 2000)." The Green Man Review. [Blog] 2013. Available URL: http://greenmanreview.com/.

Wichmann, Siegfried. Japonisme: The Japanese influence on Western art since 1858. London: Thames \& Hudson, 1981.

Willett, Edward. J.R.R. Tolkien: Master of Imaginary Worlds. Berkeley Heights: Enslow Publishers. 2004. 